\title{
PERANCANGAN SISTEM DIAGONOSA PENYAKIT HEPATITIS MENGGUNAKAN METODE KNN
}

\author{
Risa Helilintar ${ }^{1}$, Siti Rochana ${ }^{2}$,Risky Aswi Ramadhani ${ }^{3}$ \\ ${ }^{1}$ Risa.Helilintar@gmail.com, 22shirofull65@gmail.com,_2risky_aswi@unpkediri.ac.id \\ $1,2,3$ Universitas Nusantara PGRI Kediri
}

\begin{abstract}
Abstrak
Indonesia merupakan negara yang terletak di khatulistiwa, sehingga Indonesia beriklim tropis. Negara yang beriklim tropis sering mendapatkan permasalahan yaitu adanya penyakit menular seperti Hepatitis. Pada saat ini di dunia diperkirakan terdapat kira-kira 350 juta orang pengidap (carier) HBsAg, sedangkan di Indonesia Penderita Hepatitis mencapai 2,9 juta. Untuk menyelesaikan persoalan ini perlu dilakukan pengobatan dan pencegahan. Penelitian ini akan membuat sistem yang mengenali gejala penderita Hepatitis menggunakan metode K-NEAREST NEIGHBOR. Untuk mendiagnosa digunakan beberapa variabel yaitu muntah minimal tiga kali, demam 3 hari berturutturut, warna mata kuning, BAK kuning teh, badan lemas, nafsu makan menurun, dan nyeri perut atas. Hasil diagnosa system ditunjukan pada data testing ini pasien no 246 memiliki jarak paling dekat dengan pasien no 241 , pasien 241 positiv menderita hepatitis jadi dapat diputuskan bahwa pasien 246 menderita hepatitis.
\end{abstract}

Kata kunci: Hepatitis, K-NN, diagnose, Tropis, Penyakit

\section{Pendahuluan}

Hepatitis merupakan penyakit yang banyak ditemukan didunia dan dianggap sebagai persoalan kesehatan masyarakat yang harus diselesaikan. Hal ini karena selain prevalensinya tinggi, virus hepatitis dapat menimbulkan problema pasca akut bahkan dapat terjadi cirroshis hepatitis dan karsinoma hepatoseluler primer. Sepuluh persen dari infeksi virus hepatitis akan menjadi kronik dan $20 \%$ penderita hepatitis kronik ini dalam waktu 25 tahun sejak tertular akan mengalami cirroshis hepatis dan karsinoma hepatoselluler (hepatoma) [1]. Kemungkinan akan menjadi kronik lebih tinggi bila infeksi terjadi pada usia balita dimana respon imun belum berkembang secara sempurna.

Pada saat ini didunia diperkirakan terdapat kira-kira 350 juta orang pengidap (carier) HbsAg dan 220 juta (78 \%) diantaranya terdapat di Asia termasuk Indonesia. Berdasarkan pemeriksaan HBsAg pada kelompok donor darah di Indonesia prevalensi Hepatitis berkisar antara 2,50-36,17 \% [2]. Perlu adanya penanganan kusus untuk menghentikan laju penyebaran Hepatitis. Usaha untuk mengurangi penderita Hepatitis perlu dilakukan oleh semua lapisan dengan berbagai cara. Pada penelitian sebelumya diagnosa hepatitis bersifat manual belum terkompeterisasi, penelitian sebelumnya hanya memuat bagaimana hepatits menular dan gejala-gejala hepatitis.pada penelitian sebelumnya hepatitis yang membahas makanan factor penunjang hepatitis anatara lain alcohol, dan obat-obatan[3] Penelitian ini akan membahas bagaimana mendekteksi Hepatitis dengan K-Nearest Neighbor. Perlu dibuatkan sebuah sistem yang terintegrasi dimana sistem itu dioperasikan oleh pasien, admin, dan dokter, selain itu K-Nearest Neighbor meliliki kecepatatan untuk mengolah data latih [4]. Sistem yang dapat medekteksi penyakit adalah sistem yang memiliki kecerdasan buatan. Kecerdasan buatan merupakan studi tentang bagaimana membuat komputer melakukan hal-hal yang pada saat ini dapat dilakukan lebih baik oleh manusia [5].. Penelitian ini akan menngunakan Metode K-Nearest Neighbor, tujuannya agar sistem diagnose ini terkomperisasi dan masyarakat lebih mudah mengakses.

Dengan menggunakan sistem prediksi penyakit hepatitis $K$-Nearest Neighbor masyarakat awam dapat mengenali gejala-gejala penyakit Hepatitis. Untuk mendiagnosa penyakit Hepatitis digunakan beberapa variabel anatara lain suhu badan, mual, warna mata, kondisi badan, nafsu makan, dan nyeri perut. Gejala-gejala tersebut dapat dikenali secara awam, jika masyarakat ingin berkonsultasi bisa memasukan gejala tersebut dan sistem akan memberikan jawaban. Gejala yang dimasukkan akan dicocokkan dengan data training.

Pada Metode K-Nearest Neighbor dikenal data training dan data testing. Data training diambil dari data pasien lama yang sudah di diagnosa, hasil diagnose tersebut bisa positive terkena hepatitis atau negative. Sedangkan data testing adalah data masyarakat yang akan di diagnose, untuk memutuskan pasien tersbut benar-benar kerna hepatitis atau tidak, data training dan data testing diuji kedekatanya, pasien dari data training yang paling dekat dengan data testing memiliki hasil diagnose yang sama. Jika pasien tersebut memiliki banyak kecocokan maka pasien tersebut dinyatakan menederita hepatitis dan diberikan saran untuk berobat ke rumah sakit terdekat, agar segera mendapatkan penanganan. 


\section{Jurnal Ilmiah ILKOM Volume 9 Nomor 2 Agustus 2017}

Dengan adanya sistem ini diharapkan pengetahuan masyarakat tentang penyakit hepatitis semakin meningkat. Masyarakat bisa mengetahui gejala-gejala awal penyakit Hepatitis. Angka perkembangan Hepatitis dapat ditekan.

\section{Metode}

Metode yang digunakan dalam penelitian ini adalah action reseach, Alasan digunakan metode ini adalah jika hasil tidak sesuai dengan harapan maka proses akan diulang sampai hasil yang didapat dibawah error yang ditentukan. Metode ini sangat tepat jika diterpkan pada penelitian ini, karena penelitian ini perlu dilakukan uji coba beberapa kali hingga hasilnya benar-benar valid, jika belum valid maka harus dilakukan develop ulang. Selain itu sistem ini berhubungan langsung dengan pasien jika pada sistem ini terjadi kesalahan akan berkibat fatal.Berikut ini adalah skema penggunaan Metode Action Reserch[6].

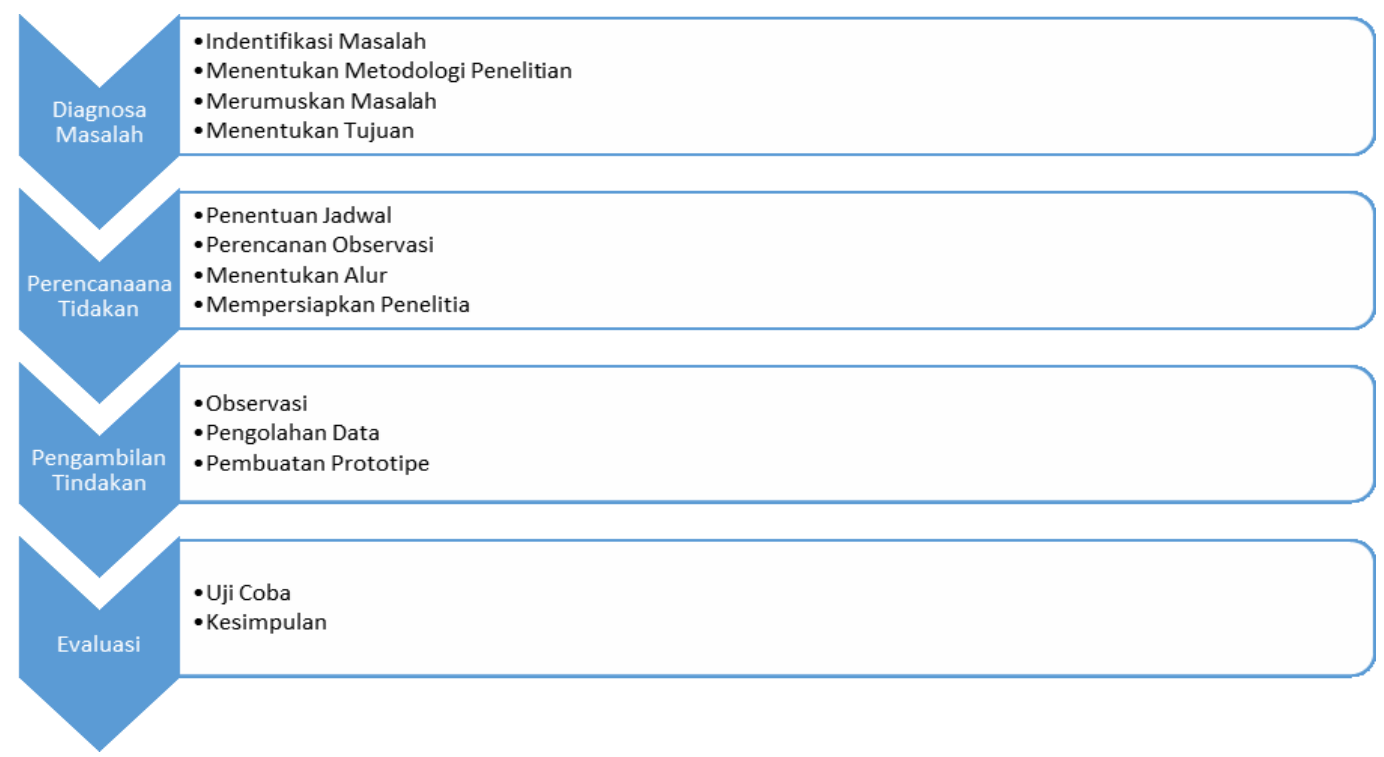

Gambar 1. Action Research

2.1. Diagnosa Masalah

\subsubsection{Identifikasi Masalah}

Identifikasi adalah memahami persalahan yang ada, pada saat ini yang menjadi permasalahan di negara tropis yang masih berkembang adalah kurangnya kesadaran masyarakat akan gejala hepatitis.

\subsubsection{Menentukan Metodologi Penelitian}

Metodologi penelitian yang tepat adalah action research karena metode ini meneliti secara detail, selain itu metode ini akan selalu mengulang jika hasil yang didapatkan saat evaluasi kurang maksimal, atau masih ada bug. Dalam penelitian ini peneliti langsung terjun ke pakar untuk melakukan obeservasi, pakar tersebut adalah dr. Ariek Kusumaningtyas

\subsubsection{Merumuskan masalah}

Rumusan masalah penelitian ini adalah bagaimana menerapkan metode $\mathrm{K}$-Nearest Neighbor untuk mendiagnosa penyakit Hepatitis.

\subsubsection{Menentukan Tujuan}

Tujuan dari penelitian ini adalah mampu mendiagnosa penyakit Hepatitis dengan metode $K$ Nearest Neighbor.

\subsection{Perencanaan Tindakan}

\subsubsection{Penentuan Jadwal}

Penelitian akan dilakukan mulai bulan mei sampai dengan bulan Agustus Tahun pada tahun

2017

\subsubsection{Perencanaan Observasi}

Observasi akan dilakukan pada bulan Mei tahun 2017, 


\section{Jurnal IImiah ILKOM Volume 9 Nomor 2 Agustus 2017}

\subsubsection{Menentukan Alur}

Berikut ini adalah alur penelitian

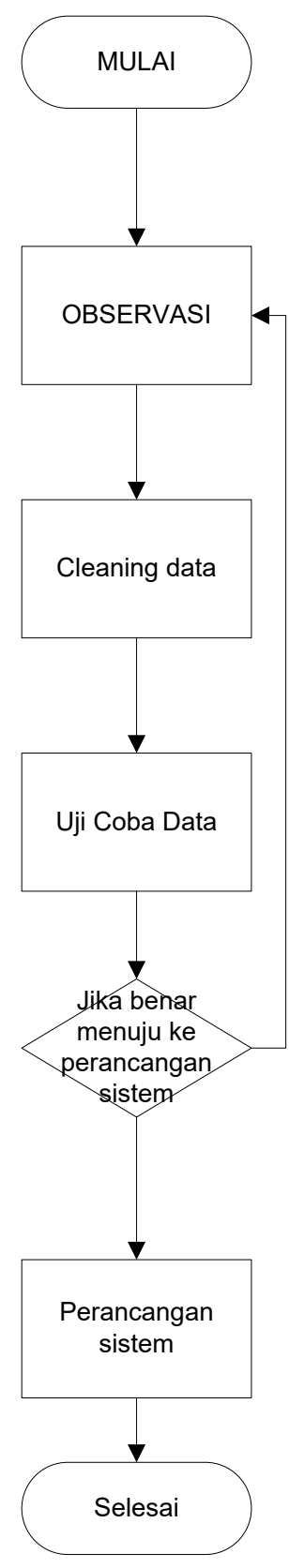

Gambar 2. Alur Penelitian

\subsubsection{Mempersiapkan penelitan}

Mempersiapkan berkas-berkas dan beberapa pertanyaan yang diajukan saat observasi, ke dokter yang memiki keahlian dalam menangani penyakit hepatitis.

\subsection{Pengambilan Tindakan}

\subsubsection{Observasi}

Observasi dilakukan untuk mengetahui gejala yang dapat mengenali penyakit hepatitis,

2.3.2 Pengolahan data

Pengolahan berfungsi untuk menormalisasikan data yang tidak perlu, sehingga data dapat diolah secara kuantitatif.

\subsubsection{Pembuatan Prototipe}

Pembuatan prototype berfungsi untuk memberikan gambara tampilan yang akan dibuat. 


\subsection{Uji Coba}

Uji coba perhitungan dilakukan beberapa kali, sebelum gejala-gejala yang ada dimasukan ke listing program yang akan dibuat di bahasa pemerograman PHP.

\section{Hasil dan Pembahasan}

\subsection{K-Nearest Neighbour (K-NN)}

Prinsip kerja $K$-Nearest Neighbour $(K-N N)$ adalah mencari jarak terdekat antara data yang akan dievaluasi dengan $k$ tetangga (Neighbour) terdekatnya dalam data petestingan. Berikut urutan proses kerja K-NN (Gorunescu, 2011):

1. Menentukan parameter $k$ (jumlah tetangga paling dekat).

2. Menghitung kuadrat jarak euclidean (euclidean distance) masing-masing obyek terhadap data sampel yang diberikan.

$$
\begin{aligned}
& \quad d_{i}=\sqrt{\sum_{i=1}^{p}\left(x_{2 i}-x_{1 i}\right)^{2}} \\
& \text { Keterangan: } \\
& x_{1}=\text { Sampel Data } \\
& x_{2}=\text { Data Uji } / \text { Testing } \\
& i=\text { Variabel Data } \\
& d=\text { Jarak } \\
& p=\text { Dimensi Data }
\end{aligned}
$$

\subsection{Variabel}

Dari hasil observasi maka ditemukan bahawa hepatitistis dapat dikenali dengan beberpa hal yaitu muntah minimal 3 kali, demam 3 hari berturut-turut, warna mata kuning, BAK kuning teh, badan lemas, nafsu makan menurun, nyeri perut atas.

Dari gejala hasil observasi maka akan digunkan metode K-NN untuk mengenali apakah orang tersebut menderita Hepatitis.

\subsection{Data Training}

Berikut ini adalah data training penederita hepatitis jumlah sebenarnya adalah 20 data training, namun hanya ditampilkan 5 , untuk lebih jelasnya dilihat pada tabel 1 .

G1=Muntah minimal 3 kali

$\mathrm{G} 2=$ Demam 3 hari berturut-turut G3=Warna Mata Kuning G4=BAK Kuning Teh
G5=Badan Lemas

G6=Nasu Makan Menurun

G7=Nyeri Perut atas

Tabel 1. Penderita dan gejala

\begin{tabular}{|l|l|l|l|l|l|l|l|l|}
\hline No & G1 & G2 & G3 & G4 & G5 & G6 & G7 & Keterangan \\
\hline 231 & Ya & Ya & Ya & Ya & Ya & Ya & Ya & Terjangkit \\
\hline 232 & Ya & Ya & Tidak & Ya & Ya & Ya & Tidak & Tidak terjangkit \\
\hline 233 & Ya & Ya & Ya & Ya & Ya & Ya & Tidak & Terjangkit \\
\hline 234 & Ya & Ya & Ya & Ya & Ya & Ya & Ya & Tidak terjangkit \\
\hline 235 & ya & ya & Ya & Ya & Ya & Ya & Ya & terjangkit \\
\hline
\end{tabular}

Pada tabel 1 dijelakan jika pasien mengalami muntah minimal 3 kali, maka pada sistem dikenali denga "ya".jika pasien demam 3 hari berturut-turut maka menjawab ya dan seterusnya, sedangakan kolom keterngan digunakan untuk hasil diagnose, jika pasien benar-benar menderita hepatitis maka diberi keterngan "terjangkit"

a. Muntah 3 kali

Tabel 2. Gejala Muntah 3 kali

\begin{tabular}{|l|r|r|}
\hline Muntah minimal 3 kali & ya & \multicolumn{1}{|l|}{ tidak } \\
\hline ya & 1 & 0 \\
\hline tidak & 0 & 1 \\
\hline
\end{tabular}




\section{Jurnal IImiah ILKOM Volume 9 Nomor 2 Agustus 2017}

Pada gejala muntah 3 kali $x=$ ya dan $y=y a$ berbobot maka bobotnya dinilai 1 , jika pada tabel muntah 3 kali pada $\mathrm{x}=\mathrm{ya}$ dan $\mathrm{y}=$ tidak maka bobot 0

\section{b. Demam 3 Hari}

Tabel 3. Gejala Demam 3 Hari

\begin{tabular}{|l|r|ll|}
\hline Muntah minimal 3 kali & ya & tidak & \\
\hline ya & 1 & 0 \\
\hline tidak & 0 & 1 \\
\hline
\end{tabular}

Demam 3 hari $x=$ ya dan $y=y a$ berbobot maka bobotnya dinilai 1 , jika pada tabel muntah 3 kali pada $\mathrm{x}=\mathrm{ya}$ dan $\mathrm{y}=$ tidak maka bobot 0

c. Warna Mata Kuning

Tabel 4. Warna Mata Kuning

\begin{tabular}{|l|r|r|}
\hline Warna Mata Kuning & ya & \multicolumn{1}{|l|}{ tidak } \\
\hline ya & 1 & 0 \\
\hline tidak & 0 & 1 \\
\hline
\end{tabular}

Mata Kuning $\mathrm{x}=$ ya dan $\mathrm{y}=\mathrm{ya}$ berbobot maka bobotnya dinilai 1 , jika pada tabel muntah 3 kali pada $x=y a$ dan $y=$ tidak maka bobot 0

d. BAK Kuning Teh

Tabel 5. BAK Kuning Teh

\begin{tabular}{|l|r|r|}
\hline Muntah minimal 3 kali & ya & \multicolumn{1}{|c|}{ tidak } \\
\hline ya & 1 & 0 \\
\hline tidak & 0 & 1 \\
\hline
\end{tabular}

BAK kuning teh $\mathrm{x}=$ ya dan $\mathrm{y}=\mathrm{ya}$ berbobot maka bobotnya dinilai 1 , jika pada tabel muntah 3 kali pada $\mathrm{x}=\mathrm{ya}$ dan $\mathrm{y}=$ tidak maka bobot 0

\section{e. Badan Lemas}

Tabel 6. Badan Lemas

\begin{tabular}{|l|r|r|}
\hline Muntah minimal 3 kali & ya & \multicolumn{1}{|c|}{ tidak } \\
\hline ya & 1 & 0 \\
\hline tidak & 0 & 1 \\
\hline
\end{tabular}

Badan Lemas $\mathrm{x}=$ ya dan $\mathrm{y}=\mathrm{ya}$ berbobot maka bobotnya dinilai 1 , jika pada tabel muntah 3 kali pada $\mathrm{x}=\mathrm{ya}$ dan $\mathrm{y}=$ tidak maka bobot 0

\section{f. Nafsu Makan Menurun}

Tabel 7. Nafsu Makan Menurun

\begin{tabular}{|l|r|r|}
\hline Muntah minimal 3 kali & ya & \multicolumn{1}{|c|}{ tidak } \\
\hline ya & 1 & 0 \\
\hline tidak & 0 & 1 \\
\hline
\end{tabular}

Nafsu Makan Menurun $\mathrm{x}=$ ya dan $\mathrm{y}=\mathrm{ya}$ berbobot maka bobotnya dinilai 1 , jika pada tabel muntah 3 kali pada $\mathrm{x}=\mathrm{ya}$ dan $\mathrm{y}=$ tidak maka bobot 0

g. Nyeri Perut atas

Tabel 8. Gejala Nyeri Perut atas

\begin{tabular}{|l|r|r|}
\hline Muntah minimal 3 kali & ya & tidak \\
\hline ya & 1 & 0 \\
\hline tidak & 0 & 1 \\
\hline
\end{tabular}

Nyeri perut atas $\mathrm{x}=$ ya dan $\mathrm{y}=\mathrm{ya}$ berbobot maka bobotnya dinilai 1 , jika pada tabel muntah 3 kali pada $\mathrm{x}=\mathrm{ya}$ dan $\mathrm{y}=$ tidak maka bobot 0

\subsection{Data Testing}

Data Testing adalah data dari pasien yang sudah diambil gejala-gejalanya, data testing akan dicocokan dengan data training untuk mencari data terdekatnya, berikut ini adalah cohtoh dari data testing

Tabel 9. Penederita dan gejala

\begin{tabular}{|l|l|l|l|l|l|l|l|l|}
\hline No & G1 & G2 & G3 & G4 & G5 & G6 & G7 & Keterangan \\
\hline 246 & Ya & Ya & Ya & Tidak & Ya & Tidak & Tidak & ? \\
\hline
\end{tabular}




\section{Jurnal Ilmiah ILKOM Volume 9 Nomor 2 Agustus 2017}

Data testing tersebut belum diketahui apakah menderita hepatitis apa tidak maka perlu dilakukan pengolahan data.

Hasil Perhitungan kedekatan data training dengan data testing

\begin{tabular}{|l|l|l|}
\hline No & Keterangan & Kedekatan \\
\hline 241 & Terjangkit & 0,83 \\
\hline 242 & Terjangkit & 0,83 \\
\hline 243 & Terjangkit & 0,66 \\
\hline 244 & Tidak terjangkit & 0,72 \\
\hline 245 & Tidak terjangkit & 0,72 \\
\hline
\end{tabular}

Dari hasil tes data testing maka, ditemukan bahwa pasien dengan ID 246 dinyatakan terjangkit, karena memiliki kedekatan dengan pasien no 241 yang bersetatus terjangkit, kedekatan pasien tersebut adalah 0,83.

\subsection{DFD Level Kontek}

Berikut ini adalah diagram level Kontek untuk Perancangan Sistem Diagonosa Penyakit Hepatitis Menggunakan Metode KNN. DFD ini terdiri dari 3 entitas yaitu admin, pasien dan Dokter

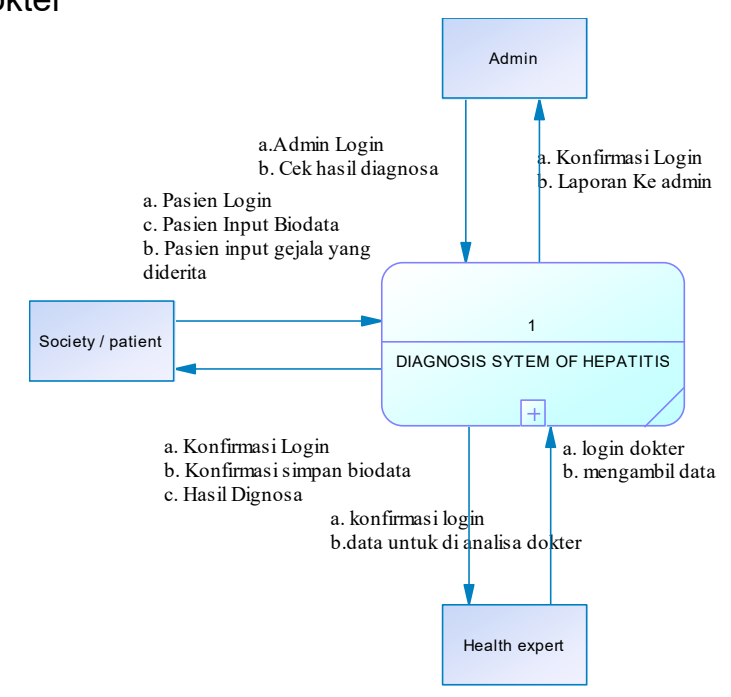

Gambar 3. DFD Level Kontex

\subsection{Prototipe}

Berikut ini adalah Prototipe Perancangan Sistem Diagonosa Penyakit Hepatitis Menggunakan Metode KNN. 


\section{Jurnal Ilmiah ILKOM Volume 9 Nomor 2 Agustus 2017}

\subsubsection{Tampilan Data Training}

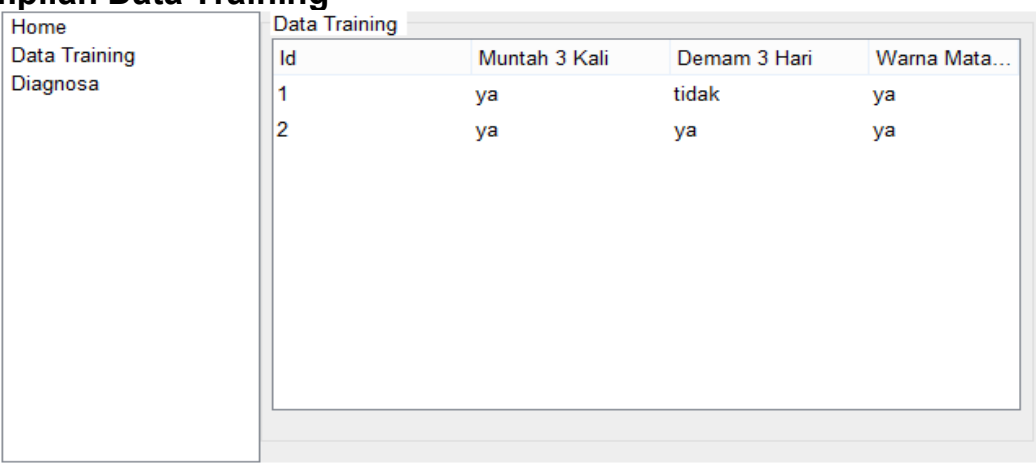

Gambar 4 Data Training

Data training adalah data psien terdahulu, data ini digunakan untuk melihat history penderita hepatitis, kegunaan data ini adalah sebagai sumber pengetahuan dari sistem

\subsubsection{Tampilan Data Testing( mendiagnosa)}

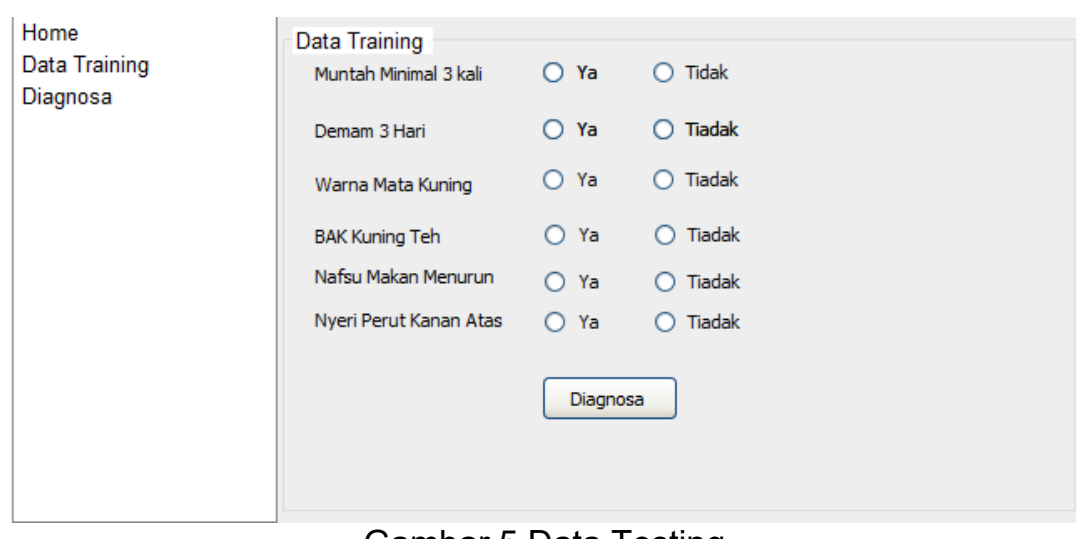

Gambar 5 Data Testing

Data testing adalah data dari pasien yang akan di diagnose, pasien yang akan di diagnose harus memasukan gejala-gejala hepatitis yang diderita

\subsubsection{Hasil Diagnosa}

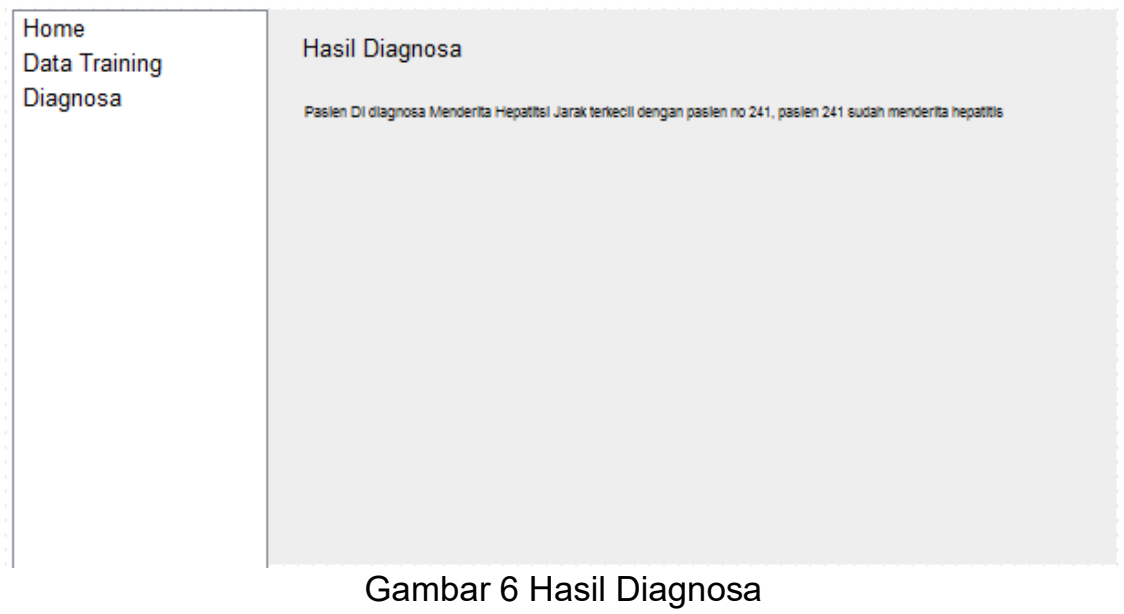

Hasil diagnosa menampilkan jarak terdekat data trainging dan data testing, pada kedekatan pasien yang diipukan paling dekat dengan pasien no 241 , nilai kedekatnya adalah 0,83, pasen 241 mederita hepatitis, jadi pasien yag di diagnose juga menederita hepatitis. 


\section{Kesimpulan dan Saran}

Dengan menggunakan variabel Muntah minimal 3 kali Demam 3 hari berturut-turut ,Warna Mata Kuning, BAK Kuning The, Badan Lemas, Nafsu makan meenurun,Nyeri perut atas. Dengan Jumlah data training 20 orang, dan 1 data testing, pada kasus ini kedekatan pasien tersebut adalah 0,83 . Dimana pasien dekat dengan pasien no 241 . Hasil yang didapat dicek ulang sangat benar. maka Metode - Nearest Neighbor dinilai akurat untuk menyelesaikan masalah hepatitis.

\section{Terima Kasih}

Saya ucapkan banyak terimakasih atas dana hibah Penelitian dosen Pemula dikti tahun 2017, dengan bantuan sumbangsih dinansisal dari dikti maka penelitian ini berjalan dengan lancar, Dengan bantuan ini maka penelitian dikampus Saya UN PGRI Kediri dapat meningkat.

\section{Daftar Pustaka}

[1] Infodatin. 2014.Situasi dan analisis Hepatitis. http://www.depkes.go.id/resources/donwload pusdatin/infodatin/infodatin-hepatitis.pdf

[2] Aguslina, Fazidah, 2011 Hepatitis Ditinjau Dari Kesehatan Masyarakat Dan Upaya Pencegahan

[3] Yogarajah, Haneethai. 2014. Laboratory Diagnosis Of Hepatitis B. JURNAL GAMMA

[4] Mutrofin, Siti. 2014. OPTIMASI TEKNIK KLASIFIKASI MODIFIED K NEAREST NEIGHBOR MENGGUNAKAN ALGORITMA GENETIKA. Udayana

[5] Stuart, Russell, Peter Norvig, 2010 Artifial Intelligence a Modern Approach Third Edition, Pearson Education, New Jersey

[6] Hasibuan, A Zaenal .2007. Metodelogi Penelitian Pada Bidang IImu Komputer dan Teknologi Informasi. 1 Juli 2017 